\title{
Evaluation of toxicity of the mycotoxin citrinin using yeast ORF DNA microarray and Oligo DNA microarray
} Hitoshi Iwahashi*1, Emiko Kitagawa1, Yoshiteru Suzuki ${ }^{1}$, Youji Ueda², Yohei Ishizawa ${ }^{2}$, Hitoshi Nobumasa ${ }^{3}$, Yoshihide Kuboki ${ }^{4}$, Hiroshi Hosoda ${ }^{5}$ and Yumiko Iwahashi ${ }^{5}$

\author{
Address: ${ }^{1}$ Human Stress Signal Research Center, National Institute of Industrial Science and Technology, AIST, Tsukuba West, Onogawa Tsukuba, \\ Ibaraki 305-8569, Japan, 2DNA Chip Research Inc. 1-1-43, Suehiro-cho, Tsurumi-ku, Yokohama, Kanagawa, 230-0045, Japan, ${ }^{3}$ Toray Industries, \\ Inc, 1111, Tebiro, Kamakura,248-8555, Kanagawa, Japan, 4Toray Industries, Inc, 1-1, Nihonbashi-Muromachi 2-chome, Chuo-ku, Tokyo 103- \\ 8666, Japan and ${ }^{5}$ National Food Research Institute, NFRI, 2-1-12 Kannondai, Tsukuba, ibaraki, 205-8642, Japan \\ Email: Hitoshi Iwahashi* - hitoshi.iwahashi@aist.go.jp; Emiko Kitagawa - e-kitagawa@aist.go.jp; \\ Yoshiteru Suzuki - yoshiteru.suzuki@aist.go.jp; Youji Ueda - yo-ueda@dna-chip.co.jp; Yo-hei Ishizawa - ishizawa@dna-chip.co.jp; \\ Hitoshi Nobumasa - hitoshi_nobumasa@nts.toray.co.jp; Yoshihide Kuboki - yoshihide_kuboki@nts.toray.co.jp; \\ Hiroshi Hosoda - hosoda@affrc.go.jp; Yumiko Iwahashi - yumiko@affrc.go.jp \\ * Corresponding author
}

Published: 5 April 2007

BMC Genomics 2007, 8:95 doi:10.1186/1471-2164-8-95

This article is available from: http://www.biomedcentral.com/I47/-2/64/8/95

(c) 2007 Iwahashi et al; licensee BioMed Central Ltd.

This is an Open Access article distributed under the terms of the Creative Commons Attribution License (http://creativecommons.org/licenses/by/2.0), which permits unrestricted use, distribution, and reproduction in any medium, provided the original work is properly cited.

\begin{abstract}
Background: Mycotoxins are fungal secondary metabolites commonly present in feed and food, and are widely regarded as hazardous contaminants. Citrinin, one of the very well known mycotoxins that was first isolated from Penicillium citrinum, is produced by more than 10 kinds of fungi, and is possibly spread all over the world. However, the information on the action mechanism of the toxin is limited. Thus, we investigated the citrinin-induced genomic response for evaluating its toxicity.

Results: Citrinin inhibited growth of yeast cells at a concentration higher than $100 \mathrm{ppm}$. We monitored the citrinin-induced mRNA expression profiles in yeast using the ORF DNA microarray and Oligo DNA microarray, and the expression profiles were compared with those of the other stress-inducing agents. Results obtained from both microarray experiments clustered together, but were different from those of the mycotoxin patulin. The oxidative stress response genes - AADs, FLRI, OYE3, GRE2, and METI 7 - were significantly induced. In the functional category, expression of genes involved in "metabolism", "cell rescue, defense and virulence", and "energy" were significantly activated. In the category of "metabolism", genes involved in the glutathione synthesis pathway were activated, and in the category of "cell rescue, defense and virulence", the $A B C$ transporter genes were induced. To alleviate the induced stress, these cells might pump out the citrinin after modification with glutathione. While, the citrinin treatment did not induce the genes involved in the DNA repair.
\end{abstract}

Conclusion: Results from both microarray studies suggest that citrinin treatment induced oxidative stress in yeast cells. The genotoxicity was less severe than the patulin, suggesting that citrinin is less toxic than patulin. The reproducibility of the expression profiles was much better with the Oligo DNA microarray. However, the Oligo DNA microarray did not completely overcome cross hybridization. 


\section{Background}

Mycotoxins are fungal secondary metabolites commonly present in the feed and food, and are widely considered as hazardous contaminants. However, the toxicity of these natural chemicals are not properly evaluated because of the difficulties in isolating these chemicals and also because of the lack of interests as they have no industrial applications. The costs for producing the pure mycotoxins are the biggest obstacle in their evaluation process. On the other hand, development of analytical methods are needed to identify new mycotoxins, to fight against the spreading toxins, and also to meet the growing demands for the toxicological studies.

Citrinin [518-75-2], 4,6-dihydro-8-hydroxy-3,4,5-trimethyl-6-oxo-3H-2-benzopyran-7-crboxylic acid (Figure 1), which was first isolated from Penicillium citrinum [1], is produced by more than 10 kinds of fungi [1]. Citrinin is the one of the well-known mycotoxins, which is possibly spread all over the world. Although citrinin is one of the well-characterized mycotoxins, information on its mechanism of toxic action is limited. Clinically, citrinin was shown to cause renal disease in poultry, pigs, dogs and rats $[2,3]$. The electron transport system of the kidney and liver mitochondria were considered as the target of the toxic action of citrinin [4].

The availability of yeast DNA microarrays provides the possibility of monitoring gene expression levels as a function of toxin exposure, and consequently, provides a mean to determine the mechanism of toxicity $[5,6]$. The essential features of this yeast system are the small volume of yeast culture required for the analysis, high reproducibility of the expression profiles and availability of the massive functional information of genes on DNA microarray $[7,8]$. For example, cadmium treatment was found

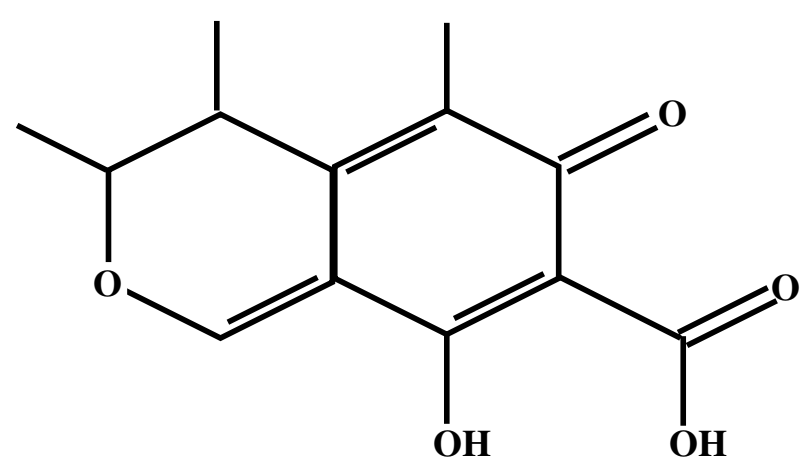

Figure I

Chemical structure of citrinin. to induce yeast genes involved in the sulfur amino acid metabolism, oxidative stress response, and heat shock response [6]. This expression pattern of induced genes was in agreement with many previous studies [6]. We applied this system to evaluate the action mechanism of patulin, one of the most potent mycotoxins, and found that patulin targets proteins and possibly DNA [7]. Our results suggested that patulin probably acts as a mutagen [7].

In this report, we studied the toxicity of citrinin to yeast cells using the traditional ORF (Open Reading Frame) DNA microarray [6] and Oligo (Oligo-nucleotide) DNA microarray systems [9]. Results from both microarray studies suggested that the oxidative stress was the main cause for toxicity, but this oxidative stress did not lead to any DNA damage. This observation was different from what was found with another mycotoxin patulin [7]. To detoxify against the citrinin, the yeast cells mainly used glutathione modification and pumped out the toxin using transporters. We have also discussed how the two DNA microarrays were adapted for evaluating the mycotoxin action.

\section{Results}

\section{Conditions for the citrinin treatment}

As a first step, we characterized the effect of citrinin on yeast growth because without any biological or physiological characterization we will not be able to prove that the induction or repression of specific genes is due to the treatment. Lack of growth inhibition would merely indicate that the conditions used for the study did not cause any cellular stress. Figure 2 shows yeast growth as a function of different concentrations of citrinin. As shown, we observed growth inhibition at concentrations greater than $108 \mathrm{ppm}$, and at $970 \mathrm{ppm}$ of citrinin there was no growth. Based on this dose-response analysis, 300 ppm of citrinin was chosen for subsequent experiments, as this concentration was found to be inhibitory to non-lethal growth (data not shown). This concentration citrinin is slightly higher than that was used for the patulin treatment [7], and citrinin may be less toxic to yeast cells.

\section{Overview of citrinin induced and repressed genes through ORF DNA microarray and Oligo DNA microarray}

From three independent citrinin treatment experiments, we obtained 12 sheets of DNA microarray results. Three sheets (OR-1, OR-2, OR-3 in Figure 3) were from the ORF DNA microarray, one from each citrinin treatment. For the Oligo DNA microarray, we performed three hybridizations for each experiment and obtained 9 sheets of data (OL-1-1, OL-1-2, OL-1-3, OL-2-1, OL-2-2, OL-2-3, OL-31, OL-3-2, OL-3-3 in Figure 3), including dye swap for the OL-1-1, OL-1-2, and OL-1-3 sheets. From the microarray data (Figure 3 ) we calculated the correlation factors to determine the reproducibility between the different 


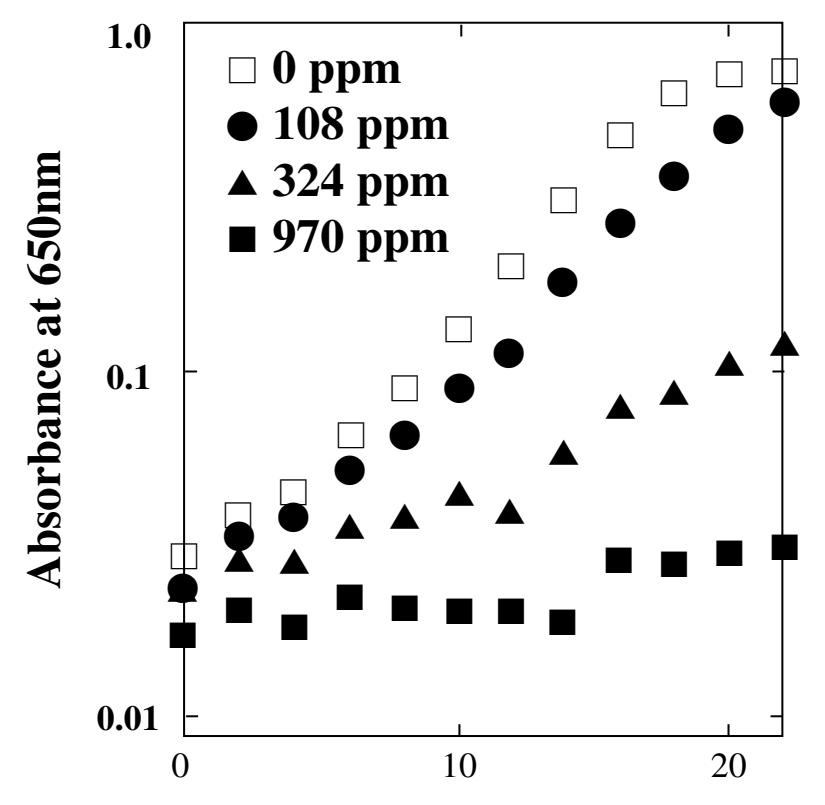

Incubation time at $25^{\circ} \mathrm{C}(\mathrm{h})$

Figure 2

Effect of citrinin on yeast growth. Citrinin dissolved in DMSO at a concentration of $20000 \mathrm{ppm}$ was added to the YPD medium to achieve the indicated concentration. The stock solution was added directly to the yeast cells grown for 2-3 days such that they were diluted more than 100 -fold.

hybridization conditions (region A in Figure 3), citrinin treatment (region B of Figure 3), dye swap (region C of Figure 3), and DNA microarray (region D in Figure 3). The correlation factors for the ORF DNA microarray were from 0.83 to 0.88 . For the Oligo DNA microarrays, the correlation factors were from 0.93 to 0.99 for 9 sheets, and from 0.96 to 0.99 for the same source of total RNA (Figure 3). The correlation factors between the ORF DNA microarray and Oligo DNA microarray showed relatively low correlation factors (0.67-0.73) than those among the same type of DNA microarray. These results suggest that the reproducibility of the Oligo DNA microarray is better than those of the ORF DNA microarray (Region B in Figure 3).

From the ORF DNA microarray, we obtained 5,928 ORFs exhibiting intensities over the cut-off value at least in one experiment. Among these ORFs, 155 ORFs showed more than two times higher intensity than that of the untreated control and having t-test P-value less than 0.05. In addition, 363 ORFs, having statistically different intensities from that of the control with the t-test P-value less than 0.01 , were recognized as induced genes. On the other hand, 73 ORFs, having two times lower intensity than that of the untreated control and having t-test P-value less than 0.05 , were recognized as repressed genes. Similarly, 471 ORFs having statistically different intensities from the control with the t-test P-value less than 0.01 were also recognized as repressed genes.

From the Oligo DNA microarray, we obtained 5,869 ORFs exhibiting intensities over the cut-off value at least in one experiment. Among these ORFs, 113 ORFs showed more than two times higher intensity than that of the untreated control and having t-test P-value less than 0.05. In addition, 801 ORFs, having statistically different intensities from the control with the t-test P-value less than 0.01, were recognized as induced genes. On the other hand, 41 ORFs, having two times lower intensity than that of the untreated control and having t-test P-value less than 0.05 , were recognized as repressed genes. Similarly, 1123 ORFs were recognized as repressed genes whose intensities were statistically different from that of the control with the ttest P-value less than 0.01. Apparently, the number of induced and repressed genes $(P<0.5)$ were higher for the ORF DNA microarray and the number of statistically significant $(P<0.01)$ induced and repressed genes were higher for the Oligo DNA microarray. These differences might arise from the different numbers of data collected from the two microarrays.

Table 1 lists the highly induced genes according to their average induction values obtained from the ORF and Oligo DNA microarrays without any statistical selection. The most highly induced gene was FRM2 followed by AADs, FLR1, OYE3, GRE2, and MET17. The most abundantly induced genes were $A A D s$. Interestingly, $A A D s$, FLR1, OYE3, GRE2, and MET17 are the genes that are significantly induced by oxidative stress $[10,11]$. The strongly repressed genes were listed in Table 2 . In contrast to the highly induced genes, there was a good agreement between the degree of repression of the repressed genes from both the ORF and Oligo DNA microarray analysis. The most strongly repressed gene was YPL095C followed by ARO10, ZRT1, USV1, CWP1, and RPI1.

To compare with the other stress factors, we carried out the cluster analysis of the ORF and Oligo DNA microarray expression data using the average value for each microarray. As shown in Figure 4, the expression profiles of the ORF microarray and Oligo microarray clustered together. The citrinin-induced response was very similar to that of the maneb. The citrinin-induced gene expression data did not cluster with those of the patulin, thiuram and acro- 
lein. These results suggest that the citrinin treatmentinduced response was not similar to that of the mycotoxin patulin. Thus, unlike patulin, which is known to target proteins $[7,12]$, citrinin might not cause protein denaturation.

\section{Functional categogorization of citrinin induced genes}

To characterize the effect of citrinin to yeast cells, the induced genes were categorized using the functional categories of MIPS. As summarized in Table 3, there were significant number of induced genes in the categories of "metabolism", "cell rescue, defense and virulence", and "energy". In addition, a high percentage of genes in these categories were found to be induced ((number of induced genes in the category/number of genes in the category) $x$ 100). In the category of "metabolism", the subcategories of "amino acid metabolism", "nitrogen and sulfur metabolism", "metabolism of vitamins", and "secondary metabolism" were significantly induced.

In the subcategories of "amino acid metabolism" and "nitrogen and sulfur metabolism", we found that the induced genes mainly belonged to the sulfur amino acid metabolism (Table 4). Among the 25 genes listed, 21 genes can be recognized as the induced genes in at least one of the DNA microarrays. These results strongly suggest that the citrinin-treated yeast cells require methionine or glutathione. In the subcategories of "metabolism of vitamins" and "secondary metabolism", there were no groups of genes specific for vitamins and secondary metabolism, but they merely overlapped with the genes for the sulfur amino acid metabolism.
Table 5 summarized the list of the induced genes belonging to the category of "cell rescue, defense and virulence". The significantly induced genes in this category were transporters, especially the ABC transporters. Several of these transporters - such as FLR1, PDR5, SNQ2, ATR1, and YOR 1 - are involved in multi-drug resistance, and are important for the tolerance against a broad range of organic anions [13-16]. It should be also noted that the GTT2 gene, which encodes the glutathione-S-transferase protein, was highly induced and the YCF1 gene, which codes for the vacuolar glutathione S-conjugate transporter, was also induced. The relatively significant induction of the genes in the "energy" category was due to the $A A D$ s and the related genes, as these genes are categorized as the dehydrogenase (data not shown).

Citrinin was suggested to cause damages to the mitochondria. Table 6 lists the cellular localization of the induced gene products. It is clear that many of these gene products, which are localized in the mitochondria, were induced; however, the proportion of these induced genes among the total number of induced genes are not so high (Table 6 , Impact). The degrees of impact values of induced genes in the mitochondria from both the microarrays were very similar to the degree of impact value of the total genes in the entries (Table 6). Although our results suggest that citrinin affected mitochondria, but we can not say that the citrinin toxicity is specific to mitochondria. In the list of highly induced genes (Table 1), the YLR346C, GTT2, PDR5, and YKL070W genes (shown in bold in Table 1) were counted as the gene products localized in the mitochondria. As these genes are also expressed in other

\begin{tabular}{|c|c|c|c|c|c|c|c|c|c|c|c|c|}
\hline & OR-1 & OR-2 & OR-3 & OL-1-1 & OL-1-2 & )L-1-3 & OL-2-1 & OL-2-2 & OL-2-3 & DL-3-1 & OL-3-2 & L-3-3 \\
\hline OR-1 & 1.00 & 0.83 & 0.88 & 0.73 & 0.72 & 0.73 & 0.71 & 0.69 & 0.72 & 0.72 & 0.73 & 0.69 \\
\hline OR-2 & & 1.00 & 0.88 & 0.72 & 0.71 & 0.71 & 0.70 & 0.67 & 0.70 & 0.70 & 0.72 & 0.68 \\
\hline OR-3 & B & & 1.00 & 0.72 & 0.71 & 0.72 & 0.69 & 0.67 & 0.70 & 0.71 & 0.72 & 0.67 \\
\hline OL-1-1 & & & & 1.00 & 0.99 & 0.99 & 0.97 & 0.95 & 0.96 & 0.96 & 0.96 & 0.93 \\
\hline OL-1-2 & & D & & & 1.00 & 0.99 & 0.97 & 0.96 & 0.96 & 0.96 & 0.96 & 0.94 \\
\hline OL-1-3 & & & & A & & 1.00 & 0.97 & 0.96 & 0.97 & 0.96 & 0.97 & 0.93 \\
\hline OL-2-1 & & & & & & & 1.00 & 0.98 & 0.98 & 0.98 & 0.98 & 0.96 \\
\hline OL-2-2 & & & & & C & & & 1.00 & 0.97 & 0.97 & 0.96 & 0.94 \\
\hline OL-2-3 & & & & & & & A & & 1.00 & 0.98 & 0.97 & 0.95 \\
\hline OL-3-1 & & & & & & & & & & 1.00 & 0.98 & 0.96 \\
\hline OL-3-2 & & & & & & & & B & & & 1.00 & 0.96 \\
\hline OL-3-3 & & & & & & & & & & A & & 1.00 \\
\hline
\end{tabular}

Figure 3

Correlation factors among the different experiments (same conditions but different treatments). A, Different sheets of microarray. B, Different citrinin treatment. C. Different labeling (dye swap), D, Different types of microarray. Dye swap was carried out with the OL-I-I, OL-I-2 and OL-I-3 sheets. 
Table I: List of highly induced genes by the citrinin treatment

\begin{tabular}{|c|c|c|c|c|c|c|c|}
\hline \multirow[b]{2}{*}{ Systematic Name } & \multirow[b]{2}{*}{ Common Name } & \multirow[b]{2}{*}{ Average (Fold) } & \multicolumn{2}{|c|}{ ORF-Array } & \multicolumn{2}{|c|}{ Oligo-Array } & \multirow[b]{2}{*}{ MIPS_Description } \\
\hline & & & Fold & t-test P-Value & Fold & t-test P-Value & \\
\hline YCL026C-A & FRM2 & 104.0 & 162.4 & 0.002 & 45.7 & 0.000 & Involved in fatty acid regulation \\
\hline YFL057C & AADI 6 & 63.5 & 86.1 & 0.003 & 40.8 & 0.000 & Aryl-alcohol dehydrogenase \\
\hline YFL056C & AAD6 & 47.0 & 39.8 & $\mathrm{NA}^{*}$ & 54.2 & 0.000 & Putative aryl-alcohol dehydrogenase, \\
\hline YDL243C & AAD4 & 46.3 & 53.4 & 0.000 & 39.2 & 0.000 & Aryl-Alcohol Dehydrogenase \\
\hline YBR008C & FLRI & 33.6 & 37.9 & 0.000 & 29.4 & 0.000 & $\begin{array}{l}\text { Putative } \mathrm{H}+\text { antiporter involved in } \\
\text { multidrug resistance }\end{array}$ \\
\hline YPLI7IC & OYE3 & 29.9 & 31.9 & 0.001 & 27.8 & 0.000 & $\begin{array}{l}\text { NAPDH dehydrogenase (old yellow } \\
\text { enzyme), isoform } 3\end{array}$ \\
\hline YOLI65C & AADI5 & 26.6 & 51.3 & 0.000 & 1.9 & 0.000 & Putative aryl alcohol dehydrogenase \\
\hline YIR04IW & PAUI5 & 23.6 & 1.7 & 0.159 & 45.3 & 0.000 & $\begin{array}{c}\text { Similarity to members of the SrpI } / \text { /Tiplp } \\
\text { family }\end{array}$ \\
\hline YJRI55W & AADIO & 22.3 & 43.7 & 0.000 & 1.0 & 0.858 & Putative aryl-alcohol dehydrogenase \\
\hline YNL33IC & AADI4 & 22.3 & 21.5 & 0.001 & 23.1 & 0.000 & Putative aryl-alcohol dehydrogenase \\
\hline YLR346C** & & 22.3 & 22.9 & 0.002 & 21.7 & 0.000 & $\begin{array}{l}\text { Protein of unknown function localised to } \\
\text { mitochondria }\end{array}$ \\
\hline YOLI5IW & GRE2 & 19.5 & 18.3 & 0.000 & 20.7 & 0.000 & $\begin{array}{c}\text { Methylglyoxal reductase (NADPH- } \\
\text { dependent) }\end{array}$ \\
\hline YCRI07W & AAD3 & 15.0 & 28.4 & 0.000 & 1.6 & 0.000 & Aryl-alcohol dehydrogenase \\
\hline YLR303W & METI7 & 14.7 & 12.3 & 0.000 & 17.1 & 0.000 & O-acetylhomoserine sulfhydrylase \\
\hline YLL056C & & 13.6 & 16.5 & 0.000 & 10.7 & 0.000 & $\begin{array}{c}\text { Weak similarity to } Y \text {. pseudotuberculosis } \\
\text { epimerase }\end{array}$ \\
\hline YLL060C*** & GTT2 & 13.2 & 13.1 & 0.000 & 13.3 & 0.000 & Glutathione S-transferase \\
\hline YORI53W* & PDR5 & 12.5 & 16.3 & 0.000 & 8.8 & 0.000 & $\begin{array}{l}A B C \text { transporter involved in multidrug } \\
\text { resistance }\end{array}$ \\
\hline YGR2I3C & RTAI & 12.3 & 9.7 & 0.001 & 15.0 & 0.000 & Integral membrane protein \\
\hline YOR049C & & 12.2 & II.I & 0.001 & 13.3 & 0.000 & Putative integral membrane transporter \\
\hline YKR076W & ECM4 & 11.2 & 11.7 & 0.000 & 10.7 & 0.000 & $\begin{array}{l}\text { Involved in cell wall biogenesis and } \\
\text { architecture }\end{array}$ \\
\hline YMLI3IW & & 10.7 & 9.2 & 0.000 & 12.2 & 0.000 & Putative hydroxydehydrogenase \\
\hline YKL070W** & & 10.7 & 9.1 & 0.020 & 12.3 & 0.000 & $\begin{array}{l}\text { Similarity to } B \text {. subtilis transcriptional } \\
\text { regulatory protein }\end{array}$ \\
\hline YILI67W & & 9.3 & 9.0 & 0.005 & 9.5 & 0.000 & Serine dehydratase \\
\hline
\end{tabular}

* NA, Not applicable (experiment was either performed less than three times or the data was not valuable

** Names indicated in bold means the genes whose products are localized in the mitochondria

organelles and are not specific to mitochondrial function, our results suggest that the effect of citrinin on mitochondria is true but not specific.

The functional categories of the repressed genes were also characterized (data not shown). As often seen with the stressed cells, the category of genes involved in "Protein synthesis" were significantly repressed but other significant character was not observed. The repression of the genes in the category of "Protein synthesis" can be the experimental marker, as this functional group is required for the actively growing cells, and not for the slowly growing or growth inhibited cells [17].

\section{Confirmation of the significantly affected genes and evaluation of both DNA microarrays}

Except the AAD15, AAD10, AAD3, and PAU15, the highly induced genes were common between the ORF DNA microarray and Oligo DNA microarray. The AAD genes have strong similarity to each other and this caused cross hybridization in the ORF DNA microarray [18]. Some of the highly induced $A A D$ genes could cross hybridize to the ORF DNA microarray spots corresponding to the AAD15, $A A D 10$, and $A A D 3$. To confirm which $A A D$ gene was really induced, we performed RT-PCR analysis. As shown in Figure 5, citrinin treatment induced the AAD4, AAD6, and $A A D 16$ genes, but not the $A A D 3, A A D 10, A A D 14$, and $A A D 15$ genes. Thus, the induction of the AAD 4, AAD6, and $A A D 16$ genes, as observed by both microarray analysis, were correct whereas the induction of the $A A D 3$, $A A D 10, A A D 14$, and $A A D 15$ genes in ORF DNA microarray and the induction of the AAD14 in Oligo DNA microarray were due to cross hybridization. We confirmed that the AAD14 probe has only one mismatch to the AAD4 ORF, and the apparent induction of the $A A D 14$ was due to the cross hybridiztion to the AAD4. In the Oligo DNA microarray, it seems that the cross hybridization has a limit of one miss match. The PAU15 gene was also highly 
Table 2: List of strongly repressed genes by the citrinin treatment

\begin{tabular}{|c|c|c|c|c|c|c|c|}
\hline \multirow[b]{2}{*}{$\begin{array}{l}\text { Systematic } \\
\text { Name }\end{array}$} & \multirow[b]{2}{*}{$\begin{array}{l}\text { Common } \\
\text { Name }\end{array}$} & \multirow[b]{2}{*}{ Average (Fold) } & \multicolumn{2}{|c|}{ ORF-Array } & \multicolumn{2}{|c|}{ Oligo-Array } & \multirow[b]{2}{*}{ MIPS_Description } \\
\hline & & & Fold & t-test $\mathrm{P}$-value & Fold & t-test $\mathrm{P}$-value & \\
\hline YPL095C & & 0.19 & 0.19 & 0.002 & 0.18 & 0.000 & Hypothetical ORF \\
\hline YDR380W & AROIO & 0.29 & 0.36 & 0.038 & 0.21 & 0.000 & $\begin{array}{l}\text { Phenylpyruvate } \\
\text { decarboxylase }\end{array}$ \\
\hline YGL255W & ZRTI & 0.33 & 0.36 & 0.015 & 0.30 & 0.000 & High-affinity zinc transporter \\
\hline YKL096W & CWPI & 0.35 & 0.38 & 0.000 & 0.32 & 0.000 & Cell wall mannoprotein \\
\hline YILII9C & RPII & 0.37 & 0.28 & 0.028 & 0.46 & 0.000 & $\begin{array}{l}\text { Putative transcriptional } \\
\text { regulator }\end{array}$ \\
\hline YHL028W & WSC4 & 0.39 & 0.51 & 0.033 & 0.28 & 0.000 & $\begin{array}{c}\text { Cell wall integrity and stress } \\
\text { response }\end{array}$ \\
\hline YHRI37W & ARO9 & 0.40 & 0.37 & 0.001 & 0.43 & 0.000 & Aromatic aminotransferase \\
\hline YPRI94C & OPT2 & 0.40 & 0.46 & 0.020 & 0.35 & 0.000 & Oligopeptide transporter \\
\hline YMRI20C & ADEI7 & 0.41 & $0.4 I$ & 0.007 & 0.41 & 0.000 & $\begin{array}{l}\text { Enzyme of 'de novo' purine } \\
\text { biosynthesis }\end{array}$ \\
\hline YAROI5W & ADEI & 0.42 & 0.31 & 0.002 & 0.54 & 0.000 & SAICAR synthetase \\
\hline YMROIIW & HXT2 & 0.43 & $0.4 I$ & 0.003 & 0.44 & 0.000 & $\begin{array}{l}\text { High-affinity glucose } \\
\text { transporter }\end{array}$ \\
\hline YPRI60W & GPHI & 0.44 & 0.41 & 0.018 & 0.47 & 0.000 & $\begin{array}{l}\text { Non-essential glycogen } \\
\text { phosphorylase }\end{array}$ \\
\hline YPL092W & SSUI & 0.44 & 0.41 & 0.009 & 0.48 & 0.000 & $\begin{array}{l}\text { Plasma membrane sulfite } \\
\text { pump }\end{array}$ \\
\hline YBL098W & & 0.45 & 0.42 & 0.002 & 0.47 & 0.000 & $\begin{array}{c}\text { Kynurenine 3-mono } \\
\text { oxygenase }\end{array}$ \\
\hline YFROI5C & GSYI & 0.45 & 0.48 & 0.024 & 0.42 & 0.000 & Glycogen synthase \\
\hline YOR3I5W & & 0.45 & 0.41 & 0.007 & 0.50 & 0.000 & Protein of unknown function, \\
\hline YDL227C & $\mathrm{HO}$ & 0.45 & 0.49 & 0.048 & 0.42 & 0.000 & Site-specific endonuclease \\
\hline
\end{tabular}

induced by citrinin treatment in Oligo DNA microarray. This gene has high similarity to other PAU genes, which were not induced. We, however, could not confirm the induction of the PAU genes by RT-PCR. Thus, the apparent induction of the PAU15 was most likely due to the cross hybridization with some highly induced unknown gene.

\section{Discussion}

Mycotoxins are fungal secondary metabolites that may be toxic to all kinds of organisms. So far, a few hundreds of mycotoxins are identified and this number can increase dramatically with the development of analytical equipment. Mycotoxins are naturally occurring chemicals. The large-scale production and industrial applications of these mycotoxins are limited, because the purification of these mycotoxins are costly and inadequate. Therefore, only a few mycotoxins were studied in detail. The DNA microarray technology provides an alternative evaluation tool to examine chemical toxicity in organisms. Particularly, the yeast DNA microarray is appropriate for evaluating the action of the mycotoxin because of the less amount of toxin required in this assay and good reproducibility of the expression profile.
Citrinin is the one of the well known mycotoxins produced by Penicillium and Aspergillus family and is possibly spread all over the world [1]. The yeast-based ORF DNA microarray and Oligo DNA microarray can provide information on the possible mechanisms of toxicity and detoxification effort by yeast cells. The list of highly induced genes in citrinin-treated yeast cells (Table 1) clearly shows that the AADs, OYE3, MET17, and GRE2 genes, which are typical indicator genes for the oxidative stress $[10,11]$, are highly induced. Thus, we can conclude that citrinin treatment causes oxidative stress. Previously, Delneli et al. [10] analyzed several $A A D$ deletion mutants and suggested that only $A A D 6$ and $A A D 4$ were induced by oxidative stress. Our RT-PCR results however suggest the $A A D 16$ gene is induced. Except oxidative stress, we could not find any other cell repair response. It was suggested that citrinin causes damage to the mitochondria. However, we could not confirm that citrinin specifically affects mitochondria. Mitochondria can be the source of oxidative stress. Thus, it is possible that the oxidative stress caused by citrinin could enhance the self-induced oxidative damages in mitochondria. The mycotoxin patulin produced response in yeast cells that was similar to that of the citrinin, as the oxidative stress related genes were also 


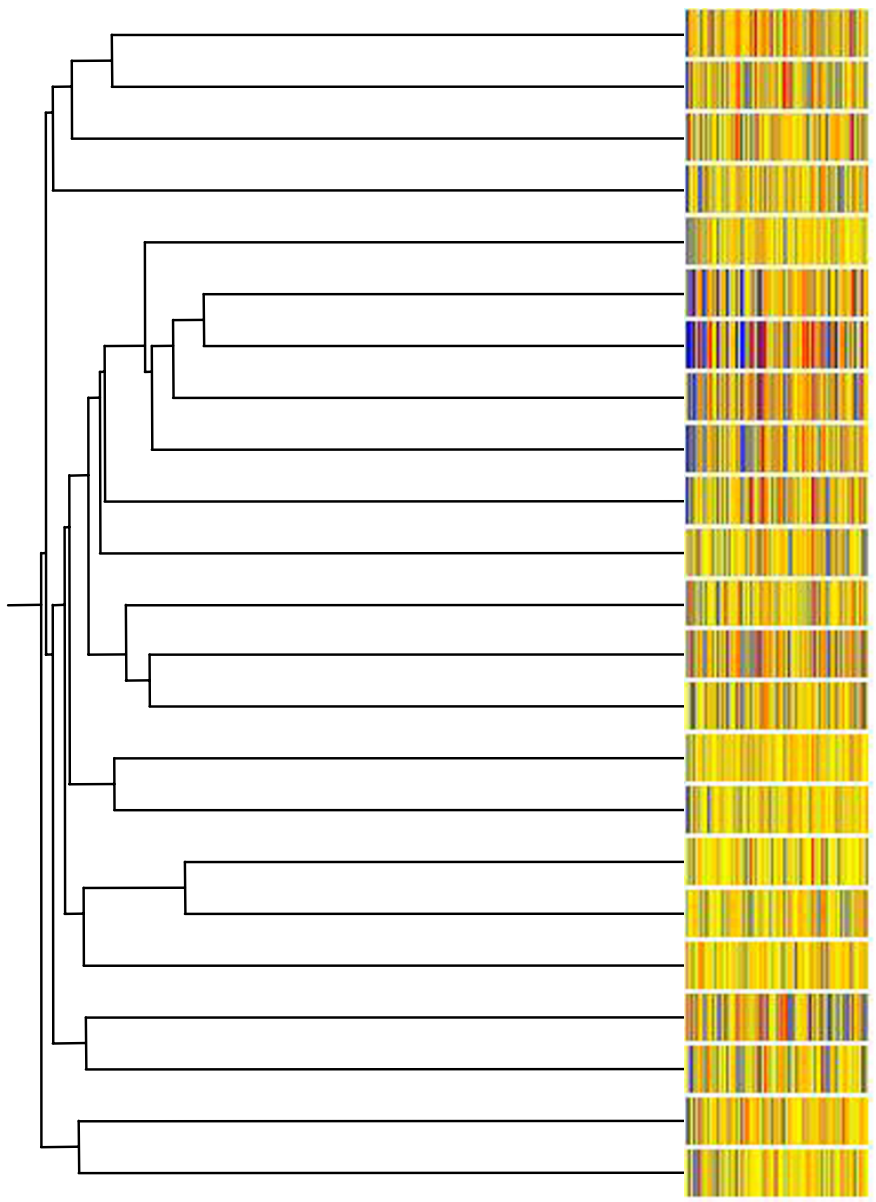

30MPa growth

Nitrogen

Nitrous oxide

Copper(2) Sulfate

Acrolein

Gingerol

TPN Standard

Thiuram Standard

Patulin

Cadmium Chloride

Zineb

Air

Carbon dioxide (CO2)

Oxygen

Capsaicin

Supiculisporic Acid

Citrinin (Oligo)

Citrinin (ORF)

Maneb

Freezing

Sodium dodecyl sulfate

180MPa 4C

40MPa 4C

\section{Figure 4}

Cluster analysis of the mRNA expression profiles after the citrinin treatment. Hierarchical cluster analysis was performed using GeneSpring as described in the text.

induced by patulin treatment [7]. In addition, the patulin treatment strongly induced the genes contributing to the protein metabolism and DNA repair, and patulin was considered as a natural mutagenic chemical [7]. However, in comparison to the patulin treatment, the citrinin treatment did not induce the genes contributing to DNA repair (Table 7). Except the oxidative stress, citrinin did not show any significant toxicity to yeast cells. The less toxicity of citrinin than the patulin was also reported in other organisms [19].

Contrast to the information concerning the mechanism of citrinin-induced toxicity, information on the detoxification mechanism was clear. The activation of the methionine and glutathione metabolisms (Table 4) strongly suggest the contribution of glutathione in the detoxification process. Moreover, strong induction of the DTT2 gene implies direct transfer of glutathione to citrinin. As the PDRs were also strongly induced (Table 5), it may be possible that the $\mathrm{ABC}$ transporters were involved in pumping out the citrinin-glutathione complex. Pumping out the toxin after glutathione modification is one of the main detoxification pathway used by many organism [19].

During the process of evaluating the citrinin toxicity, we also compared reproducibility of the ORF DNA microarray and Oligo DNA microarray. The Oligo DNA microarray showed higher correlation factor than the ORF DNA microarray (region B in Figure 2). This may have resulted from the cross hybridization exampled by AADs. The apparent induction of the AADs in the ORF DNA microarray was due to cross hybridization [7]. The Oligo DNA microarray showed less cross hybridization, as the expression levels of most of the AADs obtained from this assay agreed with the RT-PCR results. However, the Oligo DNA microarray may have limits in terms of specificity, as the $A A D 14$ gene, which has one mismatch with the AAD4 
Table 3: Contribution of induced genes to functional categories

\begin{tabular}{|c|c|c|c|c|c|c|c|c|c|}
\hline \multirow[b]{3}{*}{ Category subcategory } & \multirow[b]{3}{*}{$\begin{array}{l}\text { Total number } \\
\text { in category }\end{array}$} & \multicolumn{4}{|c|}{ ORF DNA microarray } & \multicolumn{4}{|c|}{ OligoDNA microarray } \\
\hline & & \multicolumn{2}{|c|}{$\mathrm{F}>2 \& \mathrm{P}<0.05^{*}$} & \multicolumn{2}{|l|}{$P<0.01 *$} & \multicolumn{2}{|c|}{$F>2 \& P<0.05^{*}$} & \multicolumn{2}{|l|}{$P<0.0 I^{*}$} \\
\hline & & Number & $\% *$ & Number & $\%$ & Number & $\%$ & Number & $\%$ \\
\hline Metabolism & 1521 & 54 & 3.6 & 103 & 6.8 & 51 & 2.4 & 266 & 17.0 \\
\hline amino acid metabolism & 243 & 20 & 8.2 & 33 & 13.6 & 25 & 10.3 & 81 & 33.3 \\
\hline nitrogen and sulfur metabolism & 96 & 9 & 9.4 & 15 & 15.6 & 11 & 11.5 & 39 & 40.6 \\
\hline nucleotide metabolism & 227 & 6 & 2.6 & 12 & 5.3 & 2 & 0.9 & 22 & 9.7 \\
\hline phosphate metabolism & 414 & 7 & 1.7 & 15 & 3.6 & 6 & 1.4 & 55 & 13.3 \\
\hline $\begin{array}{l}\text { C-compound and carbohydrate } \\
\text { metabolism }\end{array}$ & 504 & 18 & 3.6 & 36 & 7.1 & 19 & 3.8 & 86 & 17.1 \\
\hline $\begin{array}{l}\text { lipid, fatty acid and isoprenoid } \\
\text { metabolism }\end{array}$ & 272 & 7 & 2.6 & 20 & 7.4 & 5 & 1.8 & 30 & 11.0 \\
\hline metabolism of vitamins, & 163 & 11 & 6.7 & 16 & 9.8 & 9 & 5.5 & 40 & 24.5 \\
\hline secondary metabolism & 77 & 4 & 5.2 & 7 & 9.1 & 4 & 5.2 & 19 & 24.7 \\
\hline ENERGY & 365 & 17 & 4.7 & 34 & 9.3 & 15 & 4.1 & 59 & 16.2 \\
\hline $\begin{array}{l}\text { CELL CYCLE AND DNA } \\
\text { PROCESSING }\end{array}$ & 1001 & 9 & 0.9 & 37 & 3.7 & 4 & 0.4 & 119 & 11.9 \\
\hline TRANSCRIPTION & 1063 & 10 & 0.9 & 39 & 3.7 & 9 & 0.8 & 87 & 8.2 \\
\hline PROTEIN SYNTHESIS & 476 & 3 & 0.6 & 20 & 4.2 & 1 & 0.2 & 8 & 1.7 \\
\hline $\begin{array}{l}\text { PROTEIN FATE (folding, modification, } \\
\text { destination) }\end{array}$ & 1137 & 23 & 2.0 & 65 & 5.7 & 8 & 0.7 & 159 & 14.0 \\
\hline $\begin{array}{l}\text { PROTEIN WITH BINDING } \\
\text { FUNCTION }\end{array}$ & 1034 & 22 & 2.1 & 54 & 5.2 & 15 & 1.5 & 134 & 13.0 \\
\hline PROTEIN ACTIVITY REGULATION & 238 & 2 & 0.8 & 6 & 2.5 & I & 0.4 & 23 & 9.7 \\
\hline CELLULAR TRANSPORT & 1031 & 33 & 3.2 & 74 & 7.2 & 18 & 1.7 & $13 \mid$ & 12.7 \\
\hline CELLULAR COMMUNICATION & 234 & 1 & 0.4 & 4 & 1.7 & 1 & 0.4 & 28 & 12.0 \\
\hline $\begin{array}{l}\text { CELL RESCUE, DEFENSE AND } \\
\text { VIRULENCE }\end{array}$ & 548 & 31 & 5.7 & 47 & 8.6 & 28 & 5.1 & 118 & 21.5 \\
\hline $\begin{array}{l}\text { INTERACTION WITH THE } \\
\text { CELLULAR ENVIRONMEN }\end{array}$ & 458 & 16 & 3.5 & 28 & 6.1 & 9 & 2.0 & 71 & 15.5 \\
\hline $\begin{array}{l}\text { INTERACTION WITH THE } \\
\text { ENVIRONMENT }\end{array}$ & 5 & 0 & 0.0 & 0 & 0.0 & 0 & 0.0 & I & 20.0 \\
\hline TRANSPOSABLE ELEMENTS & 124 & 1 & 0.8 & 1 & 0.8 & 0 & 0.0 & 5 & 4.0 \\
\hline DEVELOPMENT (Systemic) & 70 & 1 & 1.4 & 4 & 5.7 & 0 & 0.0 & 7 & 10.0 \\
\hline $\begin{array}{l}\text { BIOGENESIS OF CELLULAR } \\
\text { COMPONENTS }\end{array}$ & 854 & 11 & 1.3 & 31 & 3.6 & 6 & 0.7 & 95 & II.I \\
\hline CELL TYPE DIFFERENTIATION & 449 & 3 & 0.7 & 18 & 4.0 & 2 & 0.4 & 48 & 10.7 \\
\hline UNCLASSIFIED PROTEINS & 2038 & 37 & 1.8 & 74 & 3.6 & 23 & 1.1 & 163 & 8.0 \\
\hline Total & & 155 & & 363 & & 113 & & 801 & \\
\hline
\end{tabular}


Table 4: Glutathione and methionine metabolism related genes are induced by the citrinin treatment

\begin{tabular}{|c|c|c|c|c|c|c|c|}
\hline \multirow[b]{2}{*}{ Systematic Name } & \multirow[b]{2}{*}{$\begin{array}{c}\text { Common } \\
\text { Name }\end{array}$} & \multirow[b]{2}{*}{$\begin{array}{l}\text { Average } \\
\text { (Fold) }\end{array}$} & \multicolumn{2}{|c|}{ ORF-Array } & \multicolumn{2}{|c|}{ Oligo-Array } & \multirow[b]{2}{*}{ Description } \\
\hline & & & Fold & t-test $\mathrm{P}$-value & Fold & t-test $\mathrm{P}$-value & \\
\hline YKR069W & METI & 2.6 & 2.3 & 0.002 & 2.9 & 0.000 & siroheme synthase \\
\hline YFR030W & $\overline{\text { METIO }}$ & 3.2 & 1.8 & 0.025 & 4.6 & 0.000 & sulfite reductase flavin-binding subunit \\
\hline YKL00IC & $\overline{\text { METI4 }}$ & 5.2 & 5.3 & 0.000 & 5.1 & 0.000 & ATP adenosine- $5^{\wedge}$-phosphosulfate $3^{\wedge}$-phosphotransferase \\
\hline YPRI67C & $\overline{\text { METI6 }}$ & 5.1 & 5.6 & 0.001 & 4.6 & 0.000 & $\underline{3^{\wedge} \text {-phosphoadenylylsulfate reductase }}$ \\
\hline YLR303W & METI7 & 14.7 & 12.3 & 0.000 & 17.1 & 0.000 & O-acetylhomoserine sulfhydrylase \\
\hline YNL277W & $\overline{\text { MET2 }}$ & 2.9 & 2.1 & 0.022 & 3.8 & 0.000 & homoserine O-acetyltransferase \\
\hline YOL064C & MET22 & 1.7 & 1.8 & 0.000 & 1.7 & 0.000 & protein ser/thr phosphatase \\
\hline YIROI7C & MET28 & 4.7 & 2.0 & 0.198 & 7.5 & 0.000 & transcriptional activator of sulfur amino acid metabolism \\
\hline YJROIOW & $\overline{\text { MET3 }}$ & 8.9 & 6.0 & 0.000 & 11.8 & 0.000 & sulfate adenylyltransferase \\
\hline YIL046W & $\overline{\text { MET30 }}$ & 1.1 & 1.2 & 0.203 & I.I & 0.147 & involved in regulation of sulfur assimilation genes \\
\hline YPL038W & MET3। & 1.0 & 1.2 & 0.151 & 0.9 & 0.004 & transcriptional regulator of sulfur amino acid metabolism \\
\hline YDR253C & MET32 & 2.7 & 2.2 & 0.004 & 3.3 & 0.000 & transcriptional regulator of sulfur amino acid metabolism \\
\hline YNLI03W & $\overline{\text { MET4 }}$ & 1.0 & 0.7 & 0.102 & 1.2 & 0.001 & transcriptional activator of sulfur metabolism \\
\hline YER09IC & MET6 & 2.7 & 2.6 & 0.001 & 2.7 & 0.000 & homocysteine methyltransferase \\
\hline YBR2I3W & MET8 & 1.4 & 1.2 & 0.460 & 1.6 & 0.000 & siroheme synthase \\
\hline YALOI $2 \mathrm{~W}$ & CYS3 & 2.0 & 1.9 & 0.009 & 2.0 & 0.000 & cystathionine gamma-lyase \\
\hline YGRI55W & $\overline{\mathrm{CYS4}}$ & 1.9 & 2.4 & 0.062 & 1.5 & 0.000 & cystathionine beta-synthase \\
\hline YJLIOIC & $\overline{\mathrm{GSHI}}$ & 2.4 & 2.2 & 0.000 & 2.7 & 0.000 & glutamate - cysteine ligase \\
\hline YOL049W & $\overline{\mathrm{GSH}} 2$ & 1.1 & 0.9 & 0.064 & 1.2 & 0.000 & Glutathione synthetase \\
\hline YLRI80W & $\overline{\text { SAMI }}$ & 1.4 & 1.6 & 0.023 & 1.3 & 0.000 & S-adenosylmethionine synthetase I \\
\hline YDR502C & SAM2 & 1.6 & 1.5 & 0.000 & 1.6 & 0.000 & S-adenosylmethionine synthetase 2 \\
\hline YPL274W & SAM3 & 1.2 & 1.3 & 0.015 & 1.1 & 0.124 & S-adenosylmethionine permease \\
\hline YPL273W & SAM4 & 0.9 & 0.8 & 0.010 & 1.0 & 0.008 & AdoMet-homocysteine methyltransferase \\
\hline YJRI30C & $\underline{\text { STR2 }}$ & 1.4 & 1.2 & NA & 1.6 & 0.000 & Cystathionine gamma-synthase \\
\hline YGLI84C & $\overline{\text { STR3 }}$ & 2.1 & 1.4 & 0.367 & 2.9 & 0.001 & cystathionine beta-lyase \\
\hline
\end{tabular}

* NA, Not applicable (experiment was either performed less than three times or the data was not valuable

gene, was recognized as the induced gene. On the other hand, the PAU15 gene was not recognized as the induced gene by the ORF DNA microarray and RT-PCR, but was recognized as induced gene by the Oligo DNA microarray. If the RT-PCR results were correct, these results suggest that the high specificity may not always produce correct results. Although the Oligo DNA microarray did not completely overcome the cross hybridization in the case of single mismatch, it is still a useful tool for detecting gene expression differences between similar genes.

\section{Conclusion}

Citrinin caused growth inhibition in yeast cells at a concentration more than $100 \mathrm{ppm}$. Under this condition, we monitored the citrinin treatment-induced response using the ORF DNA microarray and Oligo DNA microarray. Results obtained from these microarray experiments suggest that citrinin induced oxidative stress in the yeast cells. The citrinin-induced genotoxicity was less severe than that of the patulin. Thus, citrinin is a less toxic substance than patulin. The expression profiles obtained from both types of DNA microarrays were essentially similar. The reproducibility of the expression profiles were much better and the cross hybridization was less with the Oligo DNA microarray.

\section{Methods}

\section{Strain, growth conditions, and citrinin treatment}

Saccharomyces cerevisiae strain S288C (Mat alpha SUC2 mal mel gal2 CUP1) was grown in YPD medium $(2 \%$ polypeptone, $1 \%$ yeast extract, $2 \%$ glucose) at $25^{\circ} \mathrm{C}$ as a pre-culture for 2-3 days. This strain was used because the ORF DNA microarray probes were produced using the S288C DNA as the template for PCR [6] and because Oligo DNA microarray probes were designed based on the DNA sequence of this strain [20]. Citrinin was purchased from MP Biochemicals (Irvine, CA, USA) and was dissolved in DMSO (Dimethyl sulfoxide) to prepare a stock solution of $20000 \mathrm{ppm}$. To monitor the dose response of citrinin to yeast cells, the stock solution was added directly to the YPD medium containing the yeast cells such that they were diluted more than 100-fold. For the DNA microarray analysis, yeast cultures in YPD were diluted and grown overnight to an optical density (OD660) of 1.0. The citrinin stock solution was added to the cultures and yeast cells were allowed to grow for an additional $2 \mathrm{~h}$. For the control cells, the same volume of DMSO was 
Table 5: List of highly induced genes in the category of "CELL RESCUE, DEFENSE AND VIRULENCE"

\begin{tabular}{|c|c|c|c|c|c|c|c|}
\hline \multirow[b]{2}{*}{$\begin{array}{l}\text { Systematic } \\
\text { Name }\end{array}$} & \multirow[b]{2}{*}{$\begin{array}{c}\text { Common } \\
\text { Name }\end{array}$} & \multirow[b]{2}{*}{$\begin{array}{c}\text { Average } \\
\text { (Fold) }\end{array}$} & \multicolumn{2}{|c|}{ ORF-Array } & \multicolumn{2}{|c|}{ Oligo-Array } & \multirow[b]{2}{*}{ Description } \\
\hline & & & Fold & t-test P-value & Fold & t-test $\mathrm{P}$-value & \\
\hline YBR008C & FLRI & 33.6 & 37.9 & 0.000 & 29.4 & 0.000 & Plasma membrane multidrug transporter \\
\hline YOLI5IW & GRE2 & 19.5 & 18.3 & 0.000 & 20.7 & 0.000 & NADPH-dependent methylglyoxal reductase \\
\hline YLL060C & GTT2 & 13.2 & 13.1 & 0.000 & 13.3 & 0.000 & Glutathione S-transferase \\
\hline YORI53W & PDR5 & 12.5 & 16.3 & 0.000 & 8.8 & 0.000 & Short-lived membrane $A B C$ transporter \\
\hline YGR2I3C & RTAI & 12.3 & 9.7 & 0.001 & 15.0 & 0.000 & involved in 7-aminocholesterol resistance \\
\hline YHR048W & & 5.8 & 3.4 & 0.003 & 8.2 & 0.000 & Hypothetical ORF \\
\hline YDROIIW & SNQ2 & 5.2 & 6.6 & 0.000 & 3.8 & 0.000 & $A B C$ transporter \\
\hline YMLI I6W & ATRI & 5.2 & 5.5 & 0.000 & 4.8 & 0.000 & Multidrug efflux pump of the major facilitator superfamily \\
\hline YGR28IW & YORI & 4.6 & 4.7 & 0.000 & 4.5 & 0.000 & $A B C$ transporter \\
\hline YNL23IC & PDR I6 & 3.8 & 3.4 & 0.000 & 4.3 & 0.000 & Phosphatidylinositol transfer protein \\
\hline YHL040C & ARNI & 3.8 & 3.1 & 0.002 & 4.5 & 0.000 & Member of the ARN family of transporters \\
\hline YNLI60W & YGPI & 3.2 & 2.9 & 0.000 & 3.5 & 0.000 & May be involved in cellular adaptations prior to stationary pha \\
\hline YMR038C & LYS7 & 3.1 & 3.3 & 0.000 & 3.0 & 0.000 & Copper chaperone for superoxide dismutase Sodlp \\
\hline YGR209C & $\mathrm{TR} \times 2$ & 3.0 & 3.1 & 0.025 & 3.0 & 0.000 & Thioredoxin \\
\hline YMRI73W & DDR48 & 2.9 & 3.0 & 0.003 & 2.8 & 0.000 & DNA damage-responsive protein \\
\hline YHRI36C & SPL2 & 2.8 & 3.5 & 0.000 & 2.2 & 0.000 & Protein with similarity to cyclin-dependent kinase inhibitors \\
\hline YDR533C & & 2.8 & 3.0 & 0.000 & 2.6 & 0.000 & Possible chaperone and cysteine protease \\
\hline YER042W & MXRI & 2.6 & 2.2 & 0.001 & 2.9 & 0.000 & Peptide methionine sulfoxide reductase \\
\hline YBL064C & & 2.5 & 3.0 & 0.000 & 2.1 & 0.000 & Mitochondrial peroxiredoxin with thioredoxin peroxidase \\
\hline YERI85W & & 2.5 & 2.8 & 0.003 & 2.3 & 0.000 & Hypothetical ORF \\
\hline YDRI35C & YCF I & 2.5 & $\begin{array}{c}\text { ND } \\
*\end{array}$ & & 2.5 & 0.000 & Vacuolar glutathione S-conjugate transporter \\
\hline YDR032C & PST2 & 2.5 & 2.6 & 0.005 & 2.4 & 0.000 & Similarity to members of a family of flavodoxin-like proteins \\
\hline YJLIOIC & GSHI & 2.4 & 2.2 & 0.000 & 2.7 & 0.000 & Gamma glutamylcysteine synthetase \\
\hline
\end{tabular}

* ND, Not determined

added to the yeast culture and this was incubated for $2 \mathrm{~h}$. Cells were harvested by centrifugation and stored at $-80^{\circ} \mathrm{C}$ until used.

\section{DNA microarray analysis}

DNA microarray analysis was carried out on three independent cultures and total RNA was isolated by the hotphenol method as described previously [21].

For the ORF type DNA microarray, yeast DNA microarray Ver. 2.0 (DNA Chip Research, Inc., Yokohama, Japan) was used and the hybridization was performed using the dual color method. The Cy3- or Cy5-labeled cDNA pools were synthesized by CyScribe First-Strand cDNA Labeling Kit (GE Healthcare UK Ltd., Buckinghamshire, England). On this microarray, a total of 6,037 kinds of amplified ORFs with 200-8,000 bp length (0.1-0.5 ng) were spotted. The Cy3- or Cy5-labeled aRNA mixed pools were hybridized for $24-36 \mathrm{~h}$ at $65^{\circ} \mathrm{C}$. The details of our conditions for the microarray procedure and validation studies were previously described $[6-8,21,22]$.

For the Oligo DNA microarray, 3D-Gene Yeast Oligo Chip 6K (Toray Industries Inc., Tokyo, Japan/DNA Chip Research, Inc., Yokohama, Japan) was used. For efficient hybridization, this microarray has 3-dimensions that is constructed with a well as the space between the probes and cylinder-stems with 30-mer oligonucleotide probes on the top. Total RNA was labeled with Cy3- or Cy5- using the Amino Allyl MessageAMP II aRNA Amplificatin Kit (Applied Biosystems, CA, U.S.A.). The Cy3- or Cy5labeled aRNA pools and hybridization buffer containing micro beads were mixed, and hybridized for $16 \mathrm{~h}$. The hybridization was performed using the supplier's protocols.

\section{Data analysis}

Detected signals for each ORF were normalized by the intensity dependent (LOWESS) methods [23]. The cutoff values were the intensity of the background average plus 2SD. Genes were characterized for function according to the functional categories established by MIPS [24] and the SGD [25]. The data obtained in this experiment have been assigned accession number GSE6118 in the Gene Expression Omnibus Database [26].

Hierarchical cluster analysis was performed using the GeneSpring ver. 7.3.1 software (Silicon Genetics, CA, USA). The clustering algorithm arranges conditions according to their similarity in the expression profiles 
Table 6: Localization of the citrinin-induced gene products

\begin{tabular}{|c|c|c|c|c|c|c|c|c|c|c|}
\hline \multirow[b]{3}{*}{ Localization } & & & \multicolumn{4}{|c|}{ ORF DNA microarray } & \multicolumn{4}{|c|}{ OligoDNA microarray } \\
\hline & \multicolumn{2}{|c|}{ Entries } & \multicolumn{2}{|c|}{$F>2 \& P<0.05$} & \multicolumn{2}{|c|}{$P<0.01$} & \multicolumn{2}{|c|}{$F>2 \& P<0.05$} & \multicolumn{2}{|c|}{$P<0.01$} \\
\hline & Number & Impact* & Number & Impact & Number & Impact & Number & Impact & Number & Impact \\
\hline extracellular & 54 & 1.0 & 2 & 1.4 & 6 & 1.8 & 4 & 3.9 & 10 & 1.4 \\
\hline bud & 149 & 2.9 & 3 & 2.2 & 5 & 1.5 & 0 & 0.0 & 13 & 1.8 \\
\hline cell wall & 42 & 0.8 & I & 0.7 & 4 & 1.2 & 3 & 2.9 & 7 & 1.0 \\
\hline cell periphery & 216 & 4.1 & 11 & 8.0 & 20 & 5.9 & 8 & 7.8 & 30 & 4.2 \\
\hline plasma membrane & 186 & 3.6 & 8 & 5.8 & 18 & 5.3 & 5 & 4.9 & 29 & 4.1 \\
\hline integral membrane/endomembranes & 176 & 3.4 & 10 & 7.2 & 14 & 4.2 & 7 & 6.9 & 23 & 3.2 \\
\hline cytoplasm & 2906 & 55.8 & 94 & 68.1 & 191 & 56.7 & 76 & 74.5 & 449 & 63.2 \\
\hline cytoskeleton & 204 & 3.9 & 3 & 2.2 & 5 & 1.5 & 2 & 2.0 & 25 & 3.5 \\
\hline ER & 557 & 10.7 & 13 & 9.4 & 57 & 16.9 & 8 & 7.8 & 92 & 13.0 \\
\hline golgi & 132 & 2.5 & 2 & 1.4 & 8 & 2.4 & I & 1.0 & 16 & 2.3 \\
\hline transport vesicles & 139 & 2.7 & 2 & $\mathrm{I} .4$ & 6 & 1.8 & 0 & 0.0 & 13 & 1.8 \\
\hline nucleus & 2157 & 41.4 & 49 & 35.5 & 129 & 38.3 & 35 & 34.3 & 304 & 42.8 \\
\hline mitochondria & 1056 & 20.3 & 33 & 23.9 & 77 & 22.8 & 21 & 20.6 & 149 & 21.0 \\
\hline peroxisome & 52 & 1.0 & 2 & 1.4 & 3 & 0.9 & 0 & 0.0 & 5 & 0.7 \\
\hline endosome & 57 & I.I & I & 0.7 & 5 & 1.5 & I & 1.0 & 10 & 1.4 \\
\hline vacuole & 280 & 5.4 & 14 & 10.1 & 27 & 8.0 & 8 & 7.8 & 47 & 6.6 \\
\hline microsomes & 5 & 0.1 & 0 & 0.0 & 0 & 0.0 & 0 & 0.0 & 1 & 0.1 \\
\hline lipid particles & 27 & 0.5 & 2 & 1.4 & 4 & 1.2 & 1 & 1.0 & 3 & 0.4 \\
\hline punctate composite & $|4|$ & 2.7 & 5 & 3.6 & 9 & 2.7 & 4 & 3.9 & 15 & 2.1 \\
\hline ambiguous & 237 & 4.5 & 6 & 4.3 & 18 & 5.3 & 4 & 3.9 & 37 & 5.2 \\
\hline KNOWN LOCALIZATION & 5209 & 100 & 138 & 100 & 337 & 100 & 102 & 100 & 710 & 100 \\
\hline UNKNOWN LOCALIZATION & 1516 & & 17 & & 26 & & II & & 91 & \\
\hline
\end{tabular}
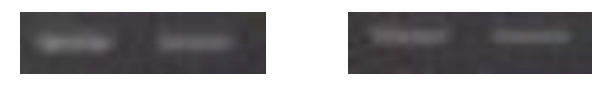

PAU15

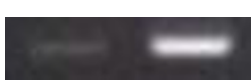

AAD6

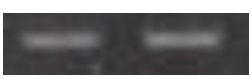

AAD3
PAU16

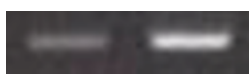

AAD16

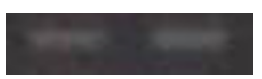

AAD14

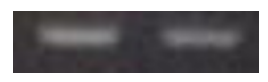

PAU21

PAU20

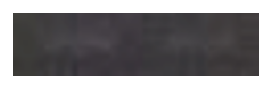

AAD15

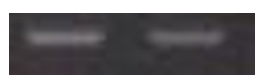

AAD10

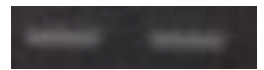

Annealed at $61^{\circ} \mathrm{C}$

PAU17

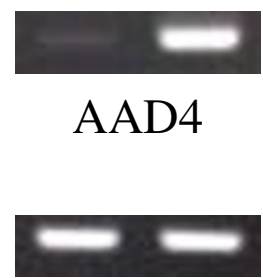

Annealed at $55^{\circ} \mathrm{C}$

ACT1

\section{Figure 5}

Confirmation of gene induction by RT-PCR. The RT-PCR analysis was performed using the primers described in Methods. Names of the genes are shown below the images. 
Table 7: Comparison of the patulin - and citrinin-induced genes contributing to DNA repair

\begin{tabular}{|c|c|c|c|c|}
\hline \multirow[b]{2}{*}{ Systematic Name } & \multicolumn{2}{|c|}{ Fold Induction } & \multirow[b]{2}{*}{ Common Name } & \multirow[b]{2}{*}{ MIPS_Description } \\
\hline & Patulin & Citrinin & & \\
\hline YDL059C & 5.7 & 1.8 & RAD59 & Recombination and DNA repair protein \\
\hline YGLI63C & 5.3 & 1.0 & RAD54 & DNA-dependent ATPase of the Snf2p family \\
\hline YGR209C & 4.4 & 3.0 & $\mathrm{TR} \times 2$ & Thioredoxin II \\
\hline YDR092W & 4.0 & 1.2 & $\mathrm{UBCI} 3$ & E2 ubiquitin-conjugating enzyme \\
\hline YERI42C & 3.9 & 1.5 & MAGI & 3-methyladenine DNA glycosylase \\
\hline YHL024W & 3.7 & 1.1 & RIM4 & No sporulation \\
\hline YFL0I4W & 3.7 & 0.9 & HSPI2 & Heat shock protein \\
\hline YPRI93C & 3.7 & 1.2 & HPA2 & Histone and other Protein Acetyltransferase \\
\hline YKLI45W & 3.5 & 1.3 & RPTI & $26 \mathrm{~S}$ proteasome regulatory subunit \\
\hline YMRI73W & 3.4 & 2.9 & DDR48 & Heat shock protein \\
\hline YAR007C & 3.4 & 1.0 & RFAI & DNA replication factor $A, 69 \mathrm{KD}$ subunit \\
\hline YPLI94W & 3.1 & I.I & DDCl & DNA damage checkpoint protein \\
\hline YLR043C & 3.0 & 1.4 & TRXI & Thioredoxin I \\
\hline YOR023C & 2.9 & 1.0 & $\mathrm{AHCl}$ & Component of the ADA histone acetyltransferase comple \\
\hline YEL037C & 2.8 & 1.1 & RAD23 & Nucleotide excision repair protein (ubiquitin-like protein) \\
\hline YMR302C & 2.8 & 0.9 & PRPI2 & Involved in early maturation of pre-rRNA \\
\hline YNL3I2W & 2.7 & 1.2 & RFA2 & DNA replication factor $A, 36 \mathrm{kDa}$ subunit \\
\hline YILI43C & 2.7 & 1.1 & SSL2 & DNA helicase \\
\hline YJR052W & 2.6 & I.I & RAD7 & Nucleotide excision repair protein \\
\hline YOL068C & 2.4 & 0.7 & HSTI & Silencing protein \\
\hline YGR23IC & 2.4 & 1.0 & PHB2 & Prohibitin \\
\hline YPR023C & 2.3 & 1.2 & EAF3 & Esalp-associated factor \\
\hline YML032C & 2.3 & 1.1 & RAD52 & Recombination and DNA repair protein \\
\hline YIR025W & 2.2 & 1.2 & MND2 & Subunit of anaphase-promoting complex \\
\hline YGL20IC & 2.1 & 1.0 & MCM6 & Involved in replication \\
\hline YMR20IC & 2.1 & 0.9 & RADI4 & Nucleotide excision repair protein \\
\hline YNL250W & 2.0 & 1.2 & RAD50 & DNA repair protein \\
\hline YCR086W & 2.0 & 1.5 & CSMI & Involved in nuclear migration \\
\hline
\end{tabular}

across all conditions, such that conditions with similar patterns are clustered together as in a taxonomic tree. Data from 3874 genes were used for the calculation. These 3874 genes were selected on the basis of having previously exhibited higher than average intensities in another trial [21].

\section{RT-PCR}

A reverse transcriptase-polymerase chain reaction (RTPCR) was carried out to confirm the result of the microarray experiments for the genes showing different patterns of expression between the ORF type microarray and the oligo probe microarray. The primers for the AADs were described previously [7]. The primers for the PAUs are:

PAU15 (YIR041W),

CTTGTTTCAAGCAGCTCATCCAAGT and ATGGAATCTCATTCGTAAAGGCATG; PAU16(YKL224C),
CTTGTTTCAAGCAGCTCATCCAAGT and CATATTCATAAAATGCTTCACG; PAU21/22 (YOR394W, YPL282C),

TACCAGATTGAGACCGGCTATC and TACTC-
CACAAACACTGTTATT; and

PAU17 (YLL025W),

GAGCTCATTTGGCTGAATACTATATG and TGCAGATAGAGCGCTGGAGATG. Total RNA prepared for the microarray analysis was used as template for the RT-PCR experiments. Reverse transcriptase reaction was performed using the StrataScript First-Strand Synthesis System (STRATAGENE, CA, USA). The cDNA mixture was diluted 20 times, and $2 \mu$ of the diluted solution was used for a $20 \mu \mathrm{l}$ PCR reaction using the TaKaRa Ex Taq HS (TaKaRa, Shiga, Japan). Annealing temperature was originally set at $55^{\circ} \mathrm{C}$. However, the PAUs showed multiple bands at $55^{\circ} \mathrm{C}$ and annealing temperature was increased to $61^{\circ} \mathrm{C}$. Each amplification reaction was resolved on a 
$2 \%$ agarose gel and the DNA bands were visualized with EtBr staining.

\section{Abbreviations}

ORF: open reading frame

Oligo: oligo-nucleotide

MIPS: Munich Information Center for Protein Sequences

SGD: Yeast Genome Database

DMSO: Dimethyl sulfoxide

RT-PCR : reverse transcriptase-polymerase chain reaction

\section{Authors' contributions}

HI planned and designed the study and wrote the main draft of the manuscript. EK analyzed the DNA microarray results and performed the RT-PCR experiments. YS performed the ORF DNA microarray experiments. YU and YI performed the Oligo DNA microarray experiments. HN and YK analyzed the Oligo DNA microarray results and contribute on the cross hybiridization search based on the ligo nucleotide on the microarray. $\mathrm{HH}$ contributed the selection of mycotoxin and planned the experiments. YI has the responsibility for the budget supporting the most part of this work and planned and performed the mycotoxin experiments. All authors read and approved the final manuscript.

\section{Acknowledgements}

This work was supported by government-subsidized grants to AIST and NFRI.

\section{References}

I. Bennett JW, Klich M: Mycotoxins. Clin Microbiol Rev 2003, 16:497-516.

2. Yu FY, Liao YC, Chang $\mathrm{CH}$, Liu BH: Citrinin induces apoptosis in HL-60 cells via activation of the mitochondrial pathway. Toxicol Lett 2006, I61:|43-I5I.

3. Reiss ]: Mycotoxins in foodstuffs $\mathbf{X}$. Production of citrinin by Penicillium chrysogenum in bread. Food Cosmet Toxicol 1977, I 5:303-307.

4. Da Lozzo EJ, Oliveira MB, Carnieri EG: Citrinin-induced mitochondrial permeability transition. J Biochem Mol Toxicol I998, | 2:29|-297.

5. Lettieri T: Recent applications of DNA microarray technology to toxicology and ecotoxicology. Environ Health Perspect 2006, I | 4:4-9.

6. Momose $\mathrm{Y}$, Iwahashi $\mathrm{H}$ : Bioassay of cadmium using a DNA microarray: genome wide expression patterns of Saccharomyces cerevisiae response to cadmium. Environ Toxicol Chem 200I, 20:2533-2360.

7. Iwahashi Y, Hosoda H, Park J, Lee J, Suzuki Y, Kitagawa E, Murata S, Jwa N, Gu M, Iwahashi $\mathrm{H}$ : Mechanisms of patulin toxicity under the condition that cause growth inhibition to yeast cells. J Agri Food Chem 2006, 54:1936-1942.

8. Mizukami S, Suzuki Y, Kitagawa E, Iwahashi H: Standardization of cDNA microarray technology for toxicogenomics; essential data for initiating cDNA microarray studies. Chem Bio Info J 2004, 4:38-55.
9. Nagino K, Nomura O, Takii Y, Myomoto A, Ichikawa M, Nakamura F, Higasa M, Akiyama H, Nobumasa H, Shiojima S, Tsujimoto G: Related Articles, Links Ultrasensitive DNA chip: gene expression profile analysis without RNA amplification. J Biochem (Tokyo) 2006, 139:697-703.

10. Delneri D, Gardner DC, Oliver SG: Analysis of the seven-member AAD gene set demonstrates that genetic redundancy in yeast may be more apparent than real. Genetics 2006, I53:1591-600.

II. Iwahashi $\mathrm{H}$ : Yeast genes that star in the cross protection against enivironmental stress. Cryobiol Cryotech 2006, 52:55-59.

12. Kitagawa E, Takahashi J, Momose $Y$, Iwahashi H: Effects of the pesticide thiuram: genome-wide screening of indicator genes by yeast DNA microarray. Environ Sci Technol 2002, 36:3908-39I 5.

13. Broco N, Tenreiro S, Viegas CA, Sa-Correia I: FLRI gene (ORF YBR008c) is required for benomyl and methotrexate resistance in Saccharomyces cerevisiae and its benomyl-induced expression is dependent on pdr3 transcriptional regulator. Yeast 1999, I 5(1 5): I 595-608.

14. Anderson JB, Sirjusingh C, Parsons AB, Boone C, Wickens C, Cowen LE, Kohn LM: Mode of selection and experimental evolution of antifungal drug resistance in Saccharomyces cerevisiae. Genetics 2003, 163:1287-98.

15. Goffeau A, Park J, Paulsen IT, Jonniaux JL, Dinh T, Mordant P, Saier $\mathrm{MH}$ Jr: Multidrug-resistant transport proteins in yeast: complete inventory and phylogenetic characterization of yeast open reading frames with the major facilitator superfamily. Yeast 1997, I 3:43-54.

16. Katzmann DJ, Hallstrom TC, Voet M, Wysock W, Golin J, Volckaert G, Moye-Rowley WS: Expression of an ATP-binding cassette transporter-encoding gene (YORI) is required for oligomycin resistance in Saccharomyces cerevisiae. Mol Cell Biol 1995, I 5:6875-83.

17. Liu BH, Yu FY, Wu TS, Li SY, Su MC, Wang MC, Shih SM: Evaluation of genotoxic risk and oxidative DNA damage in mammalian cells exposed to mycotoxins, patulin and citrinin. Toxicol Appl Pharmacol 2005, 191:255-63.

18. Ballatori N, Hammond CL, Cunningham JB, Krance SM, Marchan R: Molecular mechanisms of reduced glutathione transport: role of the MRP/CFTR/ABCC and OATP/SLC2 I A families of membrane proteins. Toxicol Appl Pharmacol 2005, 204:238-55.

19. Cole SP, Deeley RG: Transport of glutathione and glutathione conjugates by MRP I. Trends Pharmacol Sci 2006, 27:438-46.

20. Yamada T, Morishita S: Computing Highly Specific and Noise Tolerant Oligomers Efficiently. Journal of Bioinformatics and Computational Biology 2004, 2:2I-46.

21. Murata Y, Watanabe T, Sato M, Momose Y, Nakahara T, Oka S, Iwahashi $\mathrm{H}$ : DMSO exposure facilitates phospholipid biosynthesis and cellular membrane proliferation in yeast cells. $\mathrm{J} \mathrm{Biol} \mathrm{Chem}$ 2003, 278:33185-33193.

22. Mizukami S, Suzuki Y, Kitagawa E, Momose Y, Kim H, Iwahashi H: Construction of a Data Dependent Analysis (DDA) yeast cDNA microarray experiment for use in toxicogenomcs. Envir Sci 2004, I I:325-335.

23. GeneSpring Analysis Platform [http://www.silicongenetics.com/ cgi/SiG.cgi/index.smf]

24. Munich Information Center for Protein Sequences [http:// mips.gsf.de/]

25. Yeast Genome Database [http://www.yeastgenome.org/]

26. Gene Expression Omnibus Database [http:// www.ncbi.nlm.nih.gov/geo/] 